\title{
A CONCEPTUAL ARTICULATION OF TEAM TRUST ON TEAM PERFORMANCE IN UNIVERSITY SCIENTIFIC RESEARCH TEAMS IN JIANGSU PROVINCE, CHINA
}

\author{
Yu Yuni, \\ Jacquline Tham, \\ S. M. Ferdous Azam \\ Postgraduate Centre (PGC), \\ Management and Science University, \\ University Drive, Off Persiaran Olahraga, \\ 40100 Shah Alam, Selangor, \\ Malaysia
}

\begin{abstract}
:
The aim of this paper is to establish a conceptual articulation of team confidence in team success in scientific research teams at universities in the province of Jiangsu, China. Many universities have set up scientific research teams in order to produce further scientific research achievements and to promote progress. The study goals of this research are knowledge-based university science research teams. Fundamentally, the main objective of the analysis is to examine the effect of team confidence on team success in scientific research teams at universities in the province of Jiangsu, China. As this is a philosophical paper, to explain the conclusions, this analysis focuses on the empirical and theoretical articulations. Therefore, to achieve the research purpose, current research uses descriptive design as the most suitable study design. The findings indicate that the process variables have continuously attracted the attention of researchers to influence team performance; the relationship between team confidence and team performance has only begun to be explored. Team trust helps team members master team activities, minimise errors and delays, and enhance strategies to accomplish team goals, and develop creative problem-solving skills to better understand key task domains. Even, as successes in scientific research are placed into practical development. It hopes to bring tremendous economic benefits to businesses and the country.
\end{abstract}

JEL: I20; I25

Keywords: team trust, team performance, university scientific research team, Jiangsu Province, China

i Correspondence: 707816981@qq.com 


\section{Introduction}

The growing awareness that teamwork is a critical component of organisational performance has resulted in the almost ubiquitous existence of team studies in the organisation (Phungsoonthorn \& Charoensukmongkol, 2018; Azam and Moha Asri, 2015; Tham et al., 2017; Udriyah et al., 2019). Taking advantage of the various skills of the team members to deliver creative and effective results, it is important for the teams to succeed. Recent research has focused on team member interactions and team interaction structures as a primary predictor of team performance (de Wit, Greer, \& Jehn, 1995). In recent years, universities have paid considerable attention to scientific study. The degree and intensity of scientific research is now one of the key points for assessing the overall quality of a university or college. Many universities therefore set up scientific research teams in order to improve the quality of research, to improve the capacity of innovation, to increase integrated productivity, to generate more scientific research achievements and to promote growth. Scientific research achievements usually play a prominent role among innovations and creations (Duan \& Frazier, 2019). Teamwork is increasingly used in universities to supplement team members' tools, to share insightful ideas and heterogeneous information (Liu, 2016; Rachmawati et al., 2019; Azam and Yusoff, 2020; Azam et al., 2020). The degree and intensity of scientific research is now one of the key points for assessing the overall quality of a university or college. In the latest literature on university scientific research teams, it is also of great interest for the University of Science. Much of the studies concentrate on team building and team management. Intensely few studies have studied team confidence and its effect on team success. In addition, recent research (Liang, Sun \& Fonseka, 2019) shows that team confidence has a positive impact on team success. Team trust helps team members master team tasks, reduce errors and delays. In addition, team trust helps team members to strengthen approaches to achieving team goals and to develop new problem-solving skills. The goals of this analysis are the scientific research teams of the universities, which are knowledgebased. Team trust is of great importance to such organisations. The lack of team confidence will reduce the efficiency of the team. The main objective of the analysis is therefore to examine the effect of team confidence on team success in the university science research teams in Jiangsu Province, China.

\section{Literature Review}

In today's fast-changing, hyper-competitive environment, teamwork and co-operative working enhance the organisation's adaptive capability. The team, rather than the individual, is increasingly seen as the building block of organisations and a vital source of competitive advantage. Trust influences all relationships between groups of individuals; trust is essential to the successful operation of groups or teams inside organisations (Costa, 2003). Team tasks are extensive and can involve the allocation of roles, the preparation and organising of plans, decision-making on goods and facilities, 
the development of innovative strategies and the resolution of problems. Trust is an organisational concept (Costa, 2003; Azam et al., 2014; Haur et al., 2017; Katukurunda et al., 2019) focused on the partnership between an entity and another person or group of persons. Researchers also explored the trust of individuals, associations and organisations (Costa, 2003), because teamwork is often seen as the best way to deliver superior performance (Liu, 2016; Duan \& Frazier, 2019). Teamwork offers the possibility of achieving outcomes that could not be achieved by individuals working in isolation. Proposed organisational benefits of teams include enhanced productivity at work, improved quality of service, reduced management structure, lower absenteeism and reduced turnover of employees and increased organisational efficiency (Greer, \& Jehn, 1995). Team efficiency can be measured against a range of metrics, such as error avoidance, continuous improvement in production consistency, improved profitability, or consumer loyalty. Group loyalty analysis suggests that confidence enhances the willingness of community leaders to work together, with higher rates of commitment resulting in improved team results, top team happiness, high engagement (Costa, 2003; Dewi et al., 2019; Nguyen et al., 2019). Developing high-performance teams that can fulfil their demanding and dynamic responsibilities is only possible where there is a high level of cooperation between team members. But the co-operation desired in teamwork should be continuous, intensive and should be habitual behaviour for team members. This can only be achieved, providing that trust comes to be the primary value of the team culture. Trust also provides an atmosphere of psychological safety for team members, and only in such an atmosphere can members accept criticisms easily, discuss mistakes and express their thoughts freely so that they can increase synergy (Edmondson, 2001b).

Ability is a collection of talents, competencies and characteristics that enable a party to have an impact within a particular domain. The field of competence is unique as the trustee will have a substantial degree of expertise in any professional region, providing the individual with faith in the activities relating to that field. However, the trustee can have no aptitude, knowledge or expertise in specific areas, such as oral contact. While such an individual may be trusted to conduct analytical tasks relating to his or her professional field, the individual may not be trusted to establish communication with a significant consumer. Several theorists have discussed similar constructions that affect trust, using several synonyms. Cook and Wall (1980), Deutsch (1960), Jones, James, and Bruni (1975), and Sitkin and Roth (1993) all found ability to be an integral aspect of confidence. Others (e.g., Butler, 1991; Butler \& Cantrell, 1984; Kee \& Knox, 1970; Lieberman, 1981; Mishra, Rosen \& Jerdee, 1977) used the word competence to define a similar construction. Throughout the Yale studies mentioned above, presumed ability was described as a vital attribute of the trustee. Likewise, Giffin (1967) suggested that expertise should be a factor that leads to trust.

Finally, Giffin (1967) identified nine trust bases, including functional/specific competence, interpersonal competence, business sense and judgment. All of these are similar to the capabilities of the current conceptualisation. Whereas concepts such as ability and expertise represent a collection of skills common to a particular, defined area 
(e.g. Giffin's interpersonal competence), capability illustrates the task-and situationspecific complexity of the framework in the current model. Benevolence is the degree of which the trustee is supposed of wish to do something to the client, aside from an egocentric benefit motive. Benevolence implies that the trustee has a clear connection to the trustee. The partnership between a counsellor (trustee) and a guardian (trustee) is an indication of this connection. The mentor wants to help protect, even though the mentor is not required to be helpful, and there is no extrinsic reward for the mentor. Benevolence is a feeling of the trustee's optimistic attitude towards the trustee. A variety of scholars have provided traits close to benevolence as a foundation for confidence. Jones and his colleagues (1975) identified the trustworthiness of the trustee's incentive to lie. Several scholars used the term benevolence in their study of trust, concentrating on a particular partnership with the trustee (Larzelere \& Huston, 1980; Solomon, 1960). Some regarded actions or motivations as necessary to trust. While these scholars reflect the view that the trustee's orientation towards the trustee is significant, the words actions and reasons that have broader meanings than the direction towards the trustee (e.g. benefit motives of the trustee). Benevolence is a moral character that is an integral part of the suggested paradigm.

The trustor understands and analysis of the partnership history can influence both the need for confidence and the determination of trustworthiness. A robust organisational control structure may hinder the creation of trust, as the behaviour of the trustee could be perceived as a reaction to that control rather than a sign of trustworthiness. A good sense of trust for the trustee includes knowing how the meaning influences the expectations of trustworthiness.

\subsection{Theory of Performance}

Theory of Performance suggested by Don Elger, claims that six components have an impact on the level of performance: level of knowledge, skills levels, personal factors, context, level of identity, and fixed factors. The level of performance improves with the increase in the breadth and depth of knowledge. Individuals or groups can acquire knowledge involving information, theories, and concepts, principles via learning or experience. Learning is beneficial to enhance performance (Dean \& Elegwa, 2015; Maghfuriyah et al., 2019; De Silva et al., 2017; Kuruwitaarachchi et al., 2019; Pambreni et al., 2019). Theory of Performance provides theoretical support for this study to predict that there is the impact of team trust on team performance.

Chen (2013) established a model, which considered task conflict, relationship conflict as independent variables, team trust as mediator, team performance as dependent variable with the study subject of technology enterprises. Chen Jingqi (2013) found that relationship conflict was negative associated with performance. Moreover, task conflict was positive associated with performance when it was in low level. But when task conflict was in high level, it was negative associated with performance. Besides, team trust was mediator in the association between relationship conflict and performance. 
However, team trust didn't play the mediating role in the relationship between task conflict and performance.

This model centers on analysing the effects of task conflict and relationship conflict on performance. Other types of team conflict are ignored. As can be seen from conflict theory, conflict centers on the struggle of groups in society over finite resources. Hence, conflict type which is related to personal interests can be researched in-depth in future studies.

\subsection{Team Performance}

In current literature, a wide range of definitions of team performance can be found. Team performance has been defined by Lenny, Ahmad (2018) as how well a team can accomplish its output objectives, for instance, reliability and quality of team outputs, team members' expectations, efficiency, co-operative ability, innovation ability and so on. According to Lenny, Ahmad (2018), team performance refers to a multi-level process that occurs when members within a team work on managing not only their individual but also teamwork process and team work level.

Although some scholars treat team performance as a unitary construct (Wageman \& Hackman, 2005 ; Ma, 2018), many researchers suggest using varied indicators to measure team performance. For instance, Chen (2013) used innovation, effectiveness and efficiency as indicators to measure team performance. Anderson (1996) defined innovation as the intended introduction and application of new products, ideas, procedures or processes, which are devised to enhance team performance. Ma (2018) suggested that effectiveness can be defined as an absolute level of achievement of expectations and goals. The view of Lenny, Ahmad (2018) has been supported by many scholars, for example, Lenny, Ahmad (2018) also pointed out that team performance can be evaluated in terms of efficiency, effectiveness as well as innovation.

Although a wide range of definitions of the term team trust have been put forward, this paper will use the definition first suggested by Willenbrock (2017) who saw team trust as activities that members within a team seek to acquire, refine, share, or combine knowledge which is relevant to tasks through mutual communication. The definition showed a significant hallmark of team trust, which is aiming at compiling knowledge. Team trust enables team members to find effective and innovative solutions for team tasks (Timmermans, Elseviers and Denekens, 2011). It also allows team members adapt to the environmental changes, complete tasks and actualise goals swiftly (Ma, 2013).

\section{Materials and Methods}

The current study is using the descriptive design as the most appropriate study design for this kind of study. The research approach of this study is very important to achieve the research goal. Since this is a conceptual paper, this study focuses on the empirical and theoretical articulations to justify the findings. 


\section{Findings}

Although the process variables affect team performance has constantly attracted the attention of researchers, the relationship between team trust and team performance has only begun to be examined (Timmermans, Elseviers and Denekens, 2011). Most researchers (Van Offenbeek 2001; Chan \& Keasberry 2003; Ma 2018; Liang, Sun \& Fonseka, 2019) indicated that team trust had a positive impact on team performance. Team trust helps team members to master team tasks, reduce mistakes and delays (Ma, 2013; Chun et al., 2019; Yang et al., 2019). Moreover, team trust enables team members to improve approaches to achieve team goals, to develop creative problem-solving skills (Hargadon, 1999), to better understand key task domains (Liang, Moreland \& Argote, 1995), and to use fund of knowledge to shift task requirements (Han and Williams, 2008), thereby, enhancing team performance (Sun \& Fonseka, 2019). Hargadon (1999) classified team trust into team exploratory learning and team exploitative learning.

In addition, when scientific research achievements are put into practical production. This hopes to bring enormous economic benefits to the enterprises and to the country (Ma, 2013). Generally, Chinese University Scientific Research Team consists of teachers, doctor and master students. The knowledge, skills and research experiences of team members are closely related and complement each other. Leadership style as well as management is creating severe problems with the team in developing trust and group cohesion. This has negatively impacting the team's ability to establish effective communication and coordination processes to successfully complete the project (Jang, 2017; Thompson, 2011). The lack of trust between team members created emotional conflict, which affected team performance and team-member satisfaction (Lee et al., 2015). The strong emotional discontent produced strong hostility bias and created a situation in which task-based suggestions from the research members were met with antagonism and rejection from the fellow research members (Fong et al., 2018).

The team structure is too big and adding more team members will not resolve the conflict. In fact, it will cause more problems such as distorting communication and slowing down processes (Cox, 2019; Thompson, 2011). Adding sub-team sponsors at this point would definitely affect the team's decision making process. A sub-team becomes another layer within the team that information needs to be communicated to. By adding this layer, the increase for miscommunications is present as the original message can be lost as this further goes down the chain. Also, conflicts within the core group can trickle down and impact the subgroups since knowledge cannot be effectively shared (Duan \& Frazier, 2019; Sheng \& Yeh, 2009). This was present in the case. Currently, the team is dominated by the project manager, which is negatively impacting the team's performance. 


\section{Conclusion and Discussion}

The acceptability question precludes the claim that a party devoted exclusively to the profit-seeking principle at all costs will be deemed to be strong in honesty (unless that principle is appropriate to the trustee). Issues such as the consistency of the previous actions of the group, the accurate communication of the trustee with different sources, the presumption that the trustee has a reasonable sense of justice, and the extent to which the conduct of the group is consistent with its terms, also affect the degree to which the party is deemed to be trustworthy. Integrity or, rather, unique constructions have been addressed as an antecedent to the trust of a number of theories. Lieberman (1981) referred to integrity as an integral aspect of trust on its own. Sitkin and Roth's (1993: 368) approach uses a particular but more limited value congruence, defined as the "compatibility of the employee's beliefs and values with the institutional values of the institution." Their methodology compares the trustee's values with those of the corporate referent, rather than the acceptability of the trustee's values to the trustee. Integrity and accuracy were the deciding criteria for confidence in the Butler and Cantrell (1984) models. Butler (1991) also referred to integrity, fairness and justice as trust standards. Integrity in the proposed model is well grounded in previous confidence approaches. It is clear from the previous discussion that the three factors of capacity, benevolence and honesty are similar to all of the previous trust work. Previous trust antecedent models either did not integrate the three variables or evolved into a substantially larger set of antecedents (e.g., Butler, 1991). These three variables appear to illustrate, in succinct terms, the variance of trust within the trust for others.

\section{References}

Azam, S. M. F., Mohd Shukri, S., \& Ab Yajid, M. S. (2020). The impact of dynamic factors on the successful implementation of SAP. International Journal of Psychosocial Rehabilitation, 24(7), 5366-5376. https://doi.org/10.37200/IJPR/V24I7/PR270497.

Azam, S. M. F. and Moha Asri A. (2015). Differential Roles between Owner and Manager in Financial Practice That Contributes to Business Success: An Analysis on Malaysian Small Business, Academic Journal of Interdisciplinary Studies, 4 (1 S2): 123134.

Azam, S. M. F., \& Yusoff, S. K. M. (2020). Investment and financing analysis of automotive industry of China. International Journal of Psychosocial Rehabilitation, 24(7), 4848-4857. https://doi.org/10.37200/IJPR/V24I7/PR270464.

Azam, S. M. F., Haque, A., Sarwar, A. and Anwar, N. (2014). Training Program Effectiveness of Service Initiators: Measuring Perception of Female Employees of Bank Using Logistic Approach, Asian Research Journal of Business Management, 1 (2): 98-108. 
Butler, J. K. (1991). Toward understanding and measuring conditions of trust: Evolution of a conditions of trust inventory. Journal of Management, 17: 643-663.

Butler, J. K., \& Cantrell, R. S. (1984). A behavioral decision theory approach to modeling dyadic trust in superiors and subordinates. Psychological Reports, 55: 19-28.

Chan, C. C. A., Lim, L. and Keasberry, S. K. (2003a). Examining the linkages between team trust behaviors and team performance, The Learning Organization, 10 (4/5), 228-36.

Chen Jingqi (2013). Research on the influence of the team conflict to team performance of high-tech enterprises, master paper, Harbin Institute of Technology.

Chun, L., Tham, J. and Azam S. M. F. (2019). Corporate Competence Determining Factors in China Telecom Industry in Achieving Customer Satisfaction, European Journal of Management and Marketing Studies, 4 (3), pp.75-101

Cook, J., \& Wall, T. 1980. New work attitude measures of trust, organisational commitment, and personal need nonfulfillment. Journal of Occupational Psychology, 53: 39-52.

Costa, A. C. (2003). Work team trust and effectiveness. Personnel review, 32(5), 605-622.

Cox, K. (2019). Integrating an Innovation Organizational Culture with Cultural Intelligence in Multicultural Teams: A Case Study of an International Student Team. City University of Seattle.

De Silva, A. D. A., Khatibi, A. and Azam, S. M. F. (2017). Do the Demographic Differences Manifest in Motivation to Learn Science and Impact on Science Performance? Evidence from Sri Lanka, International Journal of Science and Mathematics Education, 16(S1), 47-67.

De Wit F. R., Gree L. L., Jehn K. A. (2012). The paradox of intragroup conflict: a metaanalysis. Journal of Applied Psychology, 97(2),360-390.

De Wit, F. R. C., Greer, L. L., and Jehn, K. A. (2013). Task conflict, information processing, and decision-making: The damaging effect of relationship conflict. Journal of Applied Psychology, 122, 177-189.

Dean Nyanza, Elegwa Mukulu, Mike Amuhaya Iravo (2015). Can performance measurement systems be used to measure effectiveness of the procurement function in an organisation? Journal of Business and Management, 17(11), 16-20.

Deutsch, M. (1960). The effect of motivational orientation upon trust and suspicion. Human Relations, 13: 123-140.

Dewi, N, Azam, S. M. F. and Yusoff, S. K. M. (2019). Factors influencing the information quality of local government financial statement and financial accountability, Management Science Letters, 9 (9): 1373-1384.

Duan, J., Xu, Y., \& Frazier, M. L. (2019). Voice Climate, TMX, and Task Interdependence: A Team-Level Study. Small Group Research, 50(2), 199-226.

Edmondson, A., Bohmer, R. M. and Pisano, G. P. (2001a). Disrupted routines: team trust and new technology implementation in hospitals. Administrative Science Quarterly, 46, 685-716. 
Edmondson, A., Bohmer, R. M. and Pisano, G. P. (2001b). Speeding up team trust, Harvard Business Review, 79 (9), 125-132.

Fong, P. S., Men, C., Luo, J., \& Jia, R. (2018). Knowledge hiding and team creativity: the contingent role of task interdependence. Management Decision, 56(2), 329-343.

Giffin, K. (1967). The contribution of studies of source credibility to a theory of interpersonal trust in the communication department. Psychological Bulletin, 68: 104-120.

Han, T. Y., and Williams, K. J. (2008). Multilevel investigation of adaptive performance individual- and team-level relationships. Group \& Organization Management, 33, 657-684.

Hargadon, A. B. (1999). Group cognition and creativity in organisations. In M. A. Neale, E. A. Mannix, \& R. Wageman (Eds.), research on managing groups and teams.137155. Greenwich, CT: JAI.

Haur, C. H., Khatibi, A. and Azam, S. M. F. (2017). Antecedents of Consumers' Perception towards Online Advertising in Malaysia: The Structure Equation Modeling Approach, European Journal of Management and Marketing Studies, 2 (3): 15-30

Jang, S. (2017). Cultural Brokerage and Creative Performance in Multicultural Teams. Organization Science, 28(6), 993-1009.

Jehn, K. A. (1995). A multimethod examination of the benefits and detriments of intragroup conflict. Administrative science quarterly, 256-282.

Jiang, Y., \& Chen, C. C. (2018). Integrating Knowledge Activities for Team Innovation: Effects of Transformational Leadership. Journal of Management, 44 (5) , 1819-1847. doi:10.1177/0149206316628641.

Jones, A. P., James, L. R., \& Bruni, J. R. (1975). Perceived leadership behavior and employee confidence in the leader as moderated by job involvement. Journal of Applied Psychology, 60: 146-149.

Karlsson, J., \& Skålén, P. (2015). Exploring front-line employee contributions to service innovation. European Journal of Marketing, 49(9/10), 1346-1365.

Katukurunda, K. G. W. K., Yajid, S. M. A, Khatibi, A. and Azam, S. M. F. (2019). Students' Satisfaction towards Biosystems Technology; Does Programme Quality Matters? (Evidence from Sri Lankan Perspectives), European Journal of Open Education and Elearning Studies, 3 (2): 174-190.

Kee, H. W., \& Knox, R. E. (1970). Conceptual and methodological considerations in the study of trust. Journal of Conflict Resolution. 14: 357-366.

Kerzner, H. (2013). Project management: a systems approach to planning, scheduling, and controlling. John Wiley \& Sons.

Kuruwitaarachchi, N., Yajid, S. M. A, Khatibi, A. and Azam, S. M. F. (2019). Enhance the use of Internet Based Advanced Communication Technologies in Small and Medium Scale Enterprises in Sri Lanka, European Journal of Social Sciences Studies, 3 (2): 44-57. 
Larzelere, R., \& Huston, T. (1980). The dyadic trust scale: Toward understanding interpersonal trust in close relationships. Journal of Marriage and the Family, 42: 595-604.

Lee, C. C., Lin, Y. H., Huang, H. H., Huang, W. W., \& Teng, H. H. (2015). The effects of task interdependence, team cooperation, and team conflict on job performance. Social Behavior and Personality: an international journal, 43(4), 529-536.

Lenny Ch. Nawangsari, Ahmad Hidayat Sutawidjaya (2018). The Effect of Styles of Leadership, Conflict Management and Communication Organization to Team Performance, International Journal of Humanities Social Sciences and Education, 5(7), 1-8.

Liang, Sun, G and Fonseka, T. (2019). Impact of environmental information disclosure and real estate segments on cost of debt: Evidence from the Chinese real estate industry, vol. 28(1), Wiley Online Library

Lieberman, J. K. 1981. The litigious society. New York: Basic Books.

Lisak, A., Erez, M., Sui, Y., \& Lee, C. (2016). The positive role of global leaders in enhancing multicultural team innovation. Journal of International Business Studies, 47(6), 655- 673.

Liu Huiqin (2016). An empirical study on influence factors of knowledge transfer performance within scientific research team in colleges, master's thesis, Zhe Jiang Institute of Technology.

Ma Lin (2018). On the dimensionality of intragroup conflict: a study of conflict and its relationship with group innovation performance, Qinhua Publishing House,7-28.

Ma Shuo (2013). The influence of team conflict on team performance, Economy and Management Publishing House, 100-136.

Mach, M., \& Baruch, Y. ( 2015). Team performance in cross cultural project teams: The moderated mediation role of consensus, heterogeneity, faultlines and trust. Cross Cultural Management, 22(3), 464-486.

Maghfuriyah, A., Azam, S. M. F. and Shukri, S. (2019). Market Structure and Islamic Banking Performance in Indonesia: An Error Correction Model, Management Science Letters, 9 (9): 1407-1418.

Mishra, A. K. In press. Organisational responses to crisis: The centrality of trust. In R. M. Kramer \& T. Tyler (Eds.), Trust in organisations. Newbury Park, CA: Sage.

Nguyen, H. N., Tham, J, Khatibi, A. and Azam, S. M. F. (2019). Enhancing the Capacity of Tax Authorities and its Impact on Transfer Pricing Activities of FDI Enterprises in Ha Noi, Ho Chi Minh, Dong Nai, and Binh Duong Province of Vietnam, Management Science Letters, 9 (8): 1299-1310.

Pambreni, Y., Khatibi, A., Azam, S. M. F. and Tham, J. (2019). The Influence of Total Quality Management toward Organization Performance, Management Science Letters, 9 (9): 1397-1406.

Peihua Dai (2015). Research on the influence of team task conflict on team decisionmaking performance, PhD paper, Xian Jiao Tong University. 
Phungsoonthorn, T., \& Charoensukmongkol, P. (2018). The Preventive Role of Transformational Leadership and Trust in the Leader on Employee Turnover Risk of Myanmar Migrant Workers in Thailand: The Moderating Role of Salary and Job Tenure. Journal of Risk Management and Insurance, 22(2), 66-82.

Rachmawati, D., Shukri, S., Azam, S. M. F. and Khatibi, A. (2019). Factors Influencing Customers' Purchase Decision of Residential Property in Selangor, Malaysia, Management Science Letters, 9 (9): 1341-1348.

Sheng, C., \& Yeh, C. (2009). The influence of a subteam's cohesion on its mother team. China-USA Business Review, 8(4), 58-64. Retrieved from EBSCOhost.

Sitkin, S. B, \& Bies, R. J. (1994). The legalisation of organisations: A multitheoretical perspective. In S. B Sitkin \& R. J. Bies (Eds.), The legalistic organisation: 19-49. Thousand Oaks, CA: Sage.

Sitkin, S. B, \& Pablo, A. L. (1992). Reconceptualising the determinants of risk behavior. Academy of Management Review, 17: 9-38.

Sitkin, S. B, \& Roth, N. L. (1993). Explaining the limited effectiveness of legalistic "remedies" for trust/distrust. Organisation Science, 4: 367-392.

Solomon, L. (1960). The influence of some types of power relationships and game strategies upon the development of interpersonal trust. Journal of Abnormal and Social Psychology, 61: 223-230.

Tham, J., Yazid, M. S. A, Khatibi, A. A. and Azam, S. M. F. (2017). Internet and Data Security - Understanding Customer Perception on Trusting Virtual Banking Security in Malaysia, European Journal of Social Sciences Studies, 2 (7): 186-207.

Thompson, L. L. (4th Ed.) (2011). Making the team: A guide for managers. New Jersey: Prentice Hall.

Timmermans, O., van Linge, R., van Petegem, P., Elseviers, M. and Denekens, J. (2011). Team trust and team composition in nursing, Journal of Workplace Learning, 23 (4), 258-275.

Udriyah, U., Tham, J. and Azam, S. M. F. (2019). The Effects of Market Orientation and Innovation on Competitive Advantage and Business Performance of Textile SMEs, Management Science Letters, 9 (9): 1419-1428.

Wageman, R., Hackman, J. R. and Lehman, E. (2005). Team diagnostic survey: development of an instrument. The Journal of Applied Behavioral Science, 41, 373398.

Willenbrock and Lehmann, N. (2017). Team trust: New Insights Through a Temporal Lens, Small Group Research, 48(2), 123-130.

Yang, Z. Z., Tham, J. and Azam S. M. F. (2019). Negative Psychological Factors and Online Shopping Behaviour: A Review Among College Students' at Tongren City in China, European Journal of Management and Marketing Studies, 4 (4), pp.40-58. 
Creative Commons licensing terms

Authors will retain copyright to their published articles agreeing that a Creative Commons Attribution 4.0 International License (CC BY 4.0) terms will be applied to their work. Under the terms of this license, no permission is required from the author(s) or publisher for members of the community to copy, distribute, transmit or adapt the article content, providing a proper, prominent and unambiguous attribution to the authors in a manner that makes clear that the materials are being reused under permission of a Creative Commons License. Views, opinions and conclusions expressed in this research article are views, opinions and conclusions of the author(s).Open Access Publishing Group and European Journal of Economic and Financial Research shall not be responsible or answerable for any loss, damage or liability caused in relation to/arising out of conflict of interests, copyright violations and inappropriate or inaccurate use of any kind content related or integrated on the research work. All the published works are meeting the Open Access Publishing requirements and can be freely accessed, shared, modified, distributed and used in educational, commercial and non-commercial purposes under a Creative Commons Attribution 4.0 International License (CC BY 4.0). 